\title{
Front Matter: Volume 8646
}

, "Front Matter: Volume 8646," Proc. SPIE 8646, Optical Metro Networks and Short-Haul Systems V, 864601 (11 July 2013); doi: 10.1117/12.2020073

SPIE. Event: SPIE OPTO, 2013, San Francisco, California, United States 


\title{
PROCEEDINGS OF SPIE
}

\section{Optical Metro Networks and Short-Haul Systems V}

\author{
Werner Weiershausen \\ Benjamin B. Dingel \\ Achyut K. Dutta \\ Atul K. Srivastava \\ Editors
}

\section{5-7 February 2013}

San Francisco, California, United States

Sponsored and Published by

SPIE 
The papers included in this volume were part of the technical conference cited on the cover and title page. Papers were selected and subject to review by the editors and conference program committee. Some conference presentations may not be available for publication. The papers published in these proceedings reflect the work and thoughts of the authors and are published herein as submitted. The publisher is not responsible for the validity of the information or for any outcomes resulting from reliance thereon.

Please use the following format to cite material from this book:

Author(s), "Title of Paper," in Optical Metro Networks and Short-Haul Systems V, edited by Werner Weiershausen, Benjamin B. Dingel, Achyut K. Dutta, Atul K. Srivastava, Proceedings of SPIE Vol. 8646 (SPIE, Bellingham, WA, 2013) Article CID Number.

ISSN: 0277-786X

ISBN: 9780819494153

Published by

SPIE

P.O. Box 10, Bellingham, Washington 98227-0010 USA

Telephone +1 3606763290 (Pacific Time) · Fax +1 3606471445

SPIE.org

Copyright (C) 2013, Society of Photo-Optical Instrumentation Engineers.

Copying of material in this book for internal or personal use, or for the internal or personal use of specific clients, beyond the fair use provisions granted by the U.S. Copyright Law is authorized by SPIE subject to payment of copying fees. The Transactional Reporting Service base fee for this volume is $\$ 18.00$ per article (or portion thereof), which should be paid directly to the Copyright Clearance Center (CCC), 222 Rosewood Drive, Danvers, MA 01923. Payment may also be made electronically through CCC Online at copyright.com. Other copying for republication, resale, advertising or promotion, or any form of systematic or multiple reproduction of any material in this book is prohibited except with permission in writing from the publisher. The CCC fee code is 0277-786X/13/\$18.00.

Printed in the United States of America.

Publication of record for individual papers is online in the SPIE Digital Library.

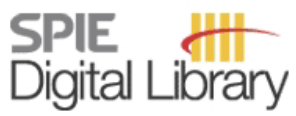

SPIEDigitallibrary.org

Paper Numbering: Proceedings of SPIE follow an e-First publication model, with papers published first online and then in print and on CD-ROM. Papers are published as they are submitted and meet publication criteria. A unique, consistent, permanent citation identifier (CID) number is assigned to each article at the time of the first publication. Utilization of CIDs allows articles to be fully citable as soon as they are published online, and connects the same identifier to all online, print, and electronic versions of the publication. SPIE uses a six-digit CID article numbering system in which:

- The first four digits correspond to the SPIE volume number.

- The last two digits indicate publication order within the volume using a Base 36 numbering system employing both numerals and letters. These two-number sets start with 00, 01, 02, 03, $04,05,06,07,08,09,0 A, 0 B \ldots 0 Z$, followed by 10-1Z, 20-2Z, etc.

The CID number appears on each page of the manuscript. The complete citation is used on the first page,

and an abbreviated version on subsequent pages. Numbers in the index correspond to the last two digits of the six-digit CID number. 


\section{Contents}

vii Conference Committee

SESSION 1 OPTICAL COMMUNICATION PLENARY SESSION: JOINT SESSION WITH CONFERENCES 8645 , 8646, AND 8647

864602 Techniques to realize flexible optical terabit-per-second transmission systems (Invited Paper) [8646-1]

M. Nölle, C. Schubert, R. Freund, Fraunhofer Institute for Telecommunications (Germany)

SESSION 2 TERABIT CAPACITY, FLEXIBLE-GRID OPTICAL TRANSMISSION SYSTEMS AND ADVANCED ACCESS NETWORK: JOINT SESSION WITH CONFERENCES 8645, 8646, AND 8647

864604 Cognition-enabling techniques in heterogeneous and flexgrid optical communication networks (Invited Paper) [8646-2]

I. Tafur Monroy, A. Caballero, S. Saldaña Cercós, R. Borkowski, Technical Univ. of Denmark (Denmark)

864605 Multicast traffic grooming in flexible optical WDM networks (Invited Paper) [8646-4] A. N. Patel, P. N. Ji, NEC Labs. America Inc. (United States); J. P. Jue, The Univ. of Texas at Dallas (United States); T. Wang, NEC Labs. America Inc. (United States)

SESSION 3 INTEGRATED NETWORK PHOTONICS DEVICES FOR NEXT-GENERATION NETWORK: JOINT SESSION WITH CONFERENCES 8645, 8646, AND 8647

864606 Integrated optical receivers using planar lightwave circuit technology (Invited Paper) [8646-6]

T. Hashimoto, NTT Photonics Labs. (Japan)

864609 A global standardization trend for high-speed client and line side transceivers (Invited Paper) [8646-7]

H. Isono, Fujitsu Optical Components (Japan)

\section{SESSION 4 FLEXIBLE AND EFFICIENT NETWORKS}

8646 OA Energy consumption and traffic scaling of dynamic optical path networks (Invited Paper) [8646-8]

K. Ishii, J. Kurumida, S. Namiki, T. Hasama, H. Ishikawa, National Institute of Advanced Industrial Science and Technology (Japan)

8646 OB The projects of Disaster-Resistant Information Communication Network at the Research Organization of Electrical Communication, Tohoku University (Invited Paper) [8646-9]

K. Iwatsuki, Tohoku Univ. (Japan) 
8646 OC Impact of wave propagation delay on latency in optical communication systems [8646-10] T. Kawanishi, A. Kanno, National Institute of Information and Communications Technology (Japan); Y. Yoshida, K. Kitayama, Osaka Univ. (Japan)

\section{SESSION $5 \quad$ INTELLIGENT AND CONVERGED NETWORK}

8646 OD Applications of bio-inspired computational intelligence in optical networks (Invited Paper) [8646-12]

J. F. Martins Filho, Federal Univ. of Pernambuco (Brazil); C. J. Bastos Filho, D. A. Chaves, Univ. of Pernambuco (Brazil)

8646 OE The benefits of converged packet/TDM/DWDM switching in metro aggregation networks (Invited Paper) [8646-13]

D. Bar On, Nokia Siemens Networks (United Kingdom); S. Voll, Nokia Siemens Networks (Germany); R. Au-Yang, Nokia Siemens Networks (United Kingdom)

8646 OF An infrastructure with a unified control plane to integrate IP into optical metro networks to provide flexible and intelligent bandwidth on demand for cloud computing [8646-29] W. Yang, T. Hall, Univ of Ottawa (Canada)

8646 OG FMCW-based monitoring and signaling for reconfigurable optical networks [8646-15] S. Gaede, M. Jastram, C. G. Schaeffer, Helmut-Schmidt-Univ. (Germany)

SESSION 7A HIGH-ORDER MODULATION FORMATS AND CODING FORMATS: JOINT SESSION WITH CONFERENCES 8646 AND 8647

8646 0J Experimental investigation of 100 -Gbps transmission over $80-\mathbf{k m}$ single mode fiber using discrete multi-tone modulation [8646-20]

T. Tanaka, M. Nishihara, T. Takahara, Fujitsu Labs. Ltd. (Japan); L. Li, Z. Tao, Fujitsu R\&D Ctr. (China); J. C. Rasmussen, Fujitsu Labs. Ltd. (Japan)

8646 OK Advanced techniques and concepts for ultra-high-speed optical networking (Invited Paper) [8646-19]

M. Cvijetic, Univ. of Arizona (United States)

SESSION 7B ADVANCED VISIBLE LIGHT COMMUNICATION SYSTEMS: JOINT SESSION WITH CONFERENCES 8645 AND 8646

$8646 \mathrm{OL}$ Application of digital signal processing in high-speed visible-light communication system (Invited Paper) [8646-18]

N. Chi, Y. Wang, Y. Wang, R. Li, H. Shang, Fudan Univ. (China) 
SESSION 8 HIGH-SPEED COMPONENTS AND SIGNAL MONITORING: JOINT SESSION WITH CONFERENCES 8646 AND 8647

8646 ON Impact of modulator chirp in $100 \mathrm{Gbps}$ class optical discrete multi-tone transmission system [8646-23]

M. Nishihara, T. Tanaka, T. Takahara, Fujitsu Labs. Ltd. (Japan); L. Li, Z. Tao, Fujitsu R\&D Ctr. (China); J. C. Rasmussen, Fujitsu Labs. Ltd. (Japan)

864600 Nyquist-WDM transmission of $7 \times 192 \mathrm{~Gb} / \mathrm{s}$ PDM 16-QAM signals using high-speed DACs operating at $42 \mathrm{GS} / \mathrm{s}$ [8646-24]

S. Yamanaka, NTT Photonics Labs. (Japan); T. Kobayashi, A. Sano, A. Matsuura, Y. Miyamoto, NTT Network Innovation Labs. (Japan); M. Nagatani, H. Nosaka, NTT Photonics Labs. (Japan)

SESSION 9 NOVEL LIGHT SOURCES, AMPLIFIERS AND DEVICES: JOINT SESSION WITH CONFERENCES 8646 AND 8647

$8646 \mathrm{OQ}$ Optical regeneration on signals beyond 100Gbps with phase-sensitive amplification (Invited Paper) [8646-26]

Y. Akasaka, J. Yang, I. Kim, M. Sekiya, Fujitsu Labs. of America, Inc. (United States)

8646 OS 1.3- $\mu \mathrm{m}$ waveband multiple-wavelength InAs/InGaAs quantum dot light source for wide wavelength range of $10 \mathrm{~Gb} / \mathrm{s}$ transmissions over 8-km long holey fiber [8646-28]

Y. Kurata, National Institute of Information and Communications Technology (Japan) and Aoyama Gakuin Univ. (Japan); N. Yamamoto, K. Akahane, T. Kawanishi, National Institute of Information and Communications Technology (Japan); H. Sotobayashi, National Institute of Information and Communications Technology (Japan) and Aoyama Gakuin Univ. (Japan); Y. Yoshioka, National Institute of Information and Communications Technology (Japan) and Tokyo Denki Univ. (Japan); H. Takai, Tokyo Denki Univ. (Japan)

Author Index 
Proc. of SPIE Vol. $8646864601-6$

Downloaded From: https://www.spiedigitallibrary.org/conference-proceedings-of-spie on 26 Apr 2023 Terms of Use: https://www.spiedigitallibrary.org/terms-of-use 


\section{Conference Committee}

Symposium Chair

David L. Andrews, University of East Anglia Norwich (United Kingdom)

Symposium Cochairs

Alexei L. Glebov, OptiGrate Corporation (United States)

Klaus P. Streubel, OSRAM GmbH (Germany)

Program Track Chair

Benjamin B. Dingel, Nasfine Photonics, Inc. (United States)

Conference Chairs

Werner Weiershausen, Deutsche Telekom AG (Germany)

Benjamin B. Dingel, Nasfine Photonics, Inc. (United States)

Achyut K. Dutta, Banpil Photonics, Inc. (United States)

Atul K. Srivastava, NEL America, Inc. (United States)

Conference Program Committee

Martin Bouda, Fujitsu Network Communications Inc. (United States)

Ronald Freund, Fraunhofer-Institut für Nachrichtentechnik HeinrichHertz-Institut (Germany)

Franko Kueppers, College of Optical Sciences, The University of Arizona (United States) and Technische Universität Darmstadt (Germany)

Shu Namiki, National Institute of Advanced Industrial Science and Technology (Japan)

Júlio César R. F. de Oliveira, Fundacao CpqD (Brazil)

Hiromi Oohashi, NTT Photonics Laboratories (Japan)

Bishnu P. Pal, Indian Institute of Technology Delhi (India)

Hans-Juergen Schmidtke, Juniper Networks, Inc. (United States)

Sascha Vorbeck, Deutsche Telekom AG (Germany)

Jianjun Yu, ZTE USA (United States) 


\section{Session Chairs}

1 Optical Communication Plenary Session: Joint Session with Conferences 8645, 8646, and 8647

Benjamin B. Dingel, Nasfine Photonics, Inc. (United States)

Atul K. Srivastava, NEL America, Inc. (United States)

2 Terabit Capacity, Flexible-Grid Optical Transmission Systems and Advanced Access Network: Joint Session with Conferences 8645 , 8646 , and 8647

Guifang Li, CREOL, The College of Optics and Photonics, University of Central Florida (United States)

Werner Weiershausen, Deutsche Telekom AG (Germany)

3 Integrated Network Photonics Devices for Next-Generation Network: Joint Session with Conferences 8645, 8646, and 8647

Martin Bouda, Fujitsu Network Communications Inc. (United States)

Benjamin B. Dingel, Nasfine Photonics, Inc. (United States)

4 Flexible and Efficient Networks

Jianjun Yu, NEC Laboratories America, Inc. (United States)

Shu Namiki, National Institute of Advanced Industrial Science and Technology (Japan)

5 Intelligent and Converged Network

Werner Weiershausen, Deutsche Telekom AG (Germany)

6 Next Generation Optical Fibers: Joint Session with Conferences 8646 and 8647

Ronald Freund, Fraunhofer-Institut für Nachrichtentechnik HeinrichHertz-Institut (Germany)

Special Session on Optical Interconnects for Short Haul Networks

Atul K. Srivastava, NEL America, Inc. (United States)

7A High-Order Modulation Formats and Coding Formats: Joint Session with Conferences 8646 and 8647

Julio C. R. F. Oliveira, CpqD Foundation (Brazil)

Guifang Li, CREOL, The College of Optics and Photonics, University of Central Florida (United States)

7B Advanced Visible Light Communication Systems: Joint Session with Conferences 8645 and 8646

Mohsen Kavehrad, The Pennsylvania State University (United States) 
8 High-Speed Components and Signal Monitoring: Joint Session with Conferences 8646 and 8647

Werner Weiershausen, Deutsche Telekom AG (Germany)

9 Novel Light Sources, Amplifiers and Devices: Joint Session with Conferences 8646 and 8647

Achyut K. Dutta, Banpil Photonics, Inc. (United States) 
Proc. of SPIE Vol. $8646864601-10$

Downloaded From: https://www.spiedigitallibrary.org/conference-proceedings-of-spie on 26 Apr 2023 Terms of Use: https://www.spiedigitallibrary.org/terms-of-use 